\title{
Translanguaging as a teaching resource in early language learning of English as a an additional language (EAL)
}

\author{
Laura Portolés and Otilia Martí \\ Universitat Jaume I, Castelló, Spain \\ (Article received 19 December 2016; accepted 26 February 2017; final version 8 March 2017) \\ DOI: http://dx.doi.org/10.5565/rev/jtl3.698
}

\begin{abstract}
Traditionally, language teaching has been grounded on a monolingual bias and the strict separation of languages has been conceived as a requirement to ensure foreign language learning success. However, the flexible use of one's linguistic repertoire, known as translanguaging, has also proven beneficial in EFL settings (vid. Jones \& Lewis, 2014).

The present study aims at examining translanguaging practices in early language learning taking into account the functions proposed by García et al. (2011). Qualitative data were collected in 3 sessions of English for 25 Valencian kindergarteners. Participants (aged 4-5) were in their second year at a Catalan-immersion school, where other two languages are taught as media of instruction (Spanish and English).

Results depict how very young language learners use their L1, L2 and L3 strategically in order to serve different communicative functions, without compromising their exposure to the target language (i.e. English). As a conclusion, we argue that a monolingual approach to teaching English as an additional language (EAL) is not a realistic picture of learners' linguistic behaviour both inside and outside the classroom in multilingual settings.
\end{abstract}

Keywords: translanguaging, linguistic repertoire, early language learning, English as an additional language (EAL), multilingual education

\section{Resum}

Tradicionalment, l'ensenyament de llengües s'ha basat en un enfocament monolingüe i l'estricta separació de llengües a l'aula s'ha considerat un requisit indefugible per garantir l'èxit d'aquest procés d'aprenentatge. No obstant això, s'ha demostrat que l'ús flexible del repertori lingüístic de l'alumnat, conegut com a translanguaging, també pot resultar beneficiós per tal d'aprendre l'anglès com a llengua estrangera (vid. Jones i Lewis, 2014).

El present estudi té com a objectiu examinar el translanguaging i les seues funcions en l'aprenentatge primerenc de llengües, tenint en compte la taxonomia proposada per García et al. (2011). Les dades, de tipus qualitatiu, es van recollir en tres classes d'anglès per a 25 pre-escolars valencians. Els i 
les participants, de 4 i 5 anys d'edat, estudiaven el segon curs de l'etapa d'Educació Infantil a un col·legi amb un programa d'immersió lingüística en català, en el qual s'utilitzen altres dues llengües com a vehicles d'instrucció (castellà i anglès).

Els resultats mostren com l'estudiantat en edat de pre-alfabetització fa servir les seves L1, L2 i L3 estratègicament per a realitzar diferents funcions comunicatives, sense comprometre l'exposició a la llengua meta, l'anglès. Com a conclusió, considerem que un enfocament monolingüe envers l'ensenyament de l'anglès com a llengua addicional (EAL) no és una imatge realista de l'ús de les llengües que fa l'alumnat tant dins com fora de l'aula en entorns multilingües.

Paraules clau: translanguaging, repertori lingüístic, aprenentatge primerenc de llengües, anglès com a llengua addicional (EAL), educació multilingüe

\section{Resumen}

Tradicionalmente, la enseñanza de lenguas ha estado marcada por un enfoque monolingüe y la estricta separación de lenguas en clase se ha considerado un requisito imprescindible para garantizar el éxito de dicho proceso de aprendizaje. Sin embargo, se ha demostrado que el uso flexible del repertorio lingüístico del estudiantado, conocido como translanguaging, también puede resultar beneficioso para aprender inglés como lengua extranjera (vid. Jones y Lewis, 2014).

El presente estudio tiene como objetivo examinar el translanguaging y las funciones que cumple, teniendo en cuenta la taxonomía propuesta por García et al. (2011). Los datos, de tipo cualitativo, provienen de 3 clases de inglés dirigidas a 25 preescolares valencianos. Los y las participantes se encontraban en el segundo curso de la etapa de Educación Infantil en un colegio que sigue un programa de inmersión lingüística en catalán, en el cual se utilizan otras dos lenguas como vehículos de instrucción (castellano e inglés).

Los resultados muestran cómo el estudiantado en edad de pre-alfabetización utiliza su L1, L2 y L3 estratégicamente para realizar diferentes funciones comunicativas, sin comprometer por ello su exposición a la lengua meta, el inglés. Como conclusión, consideramos que un enfoque monolingüe de la enseñanza del inglés como lengua adicional (EAL) no es una imagen realista del uso de las lenguas que presenta el alumnado tanto dentro como fuera del aula en entornos multilingües.

Palabras clave: translanguaging, repertorio lingüístico, aprendizaje temprano de lenguas, inglés como lengua adicional (EAL), educación multilingüe 


\section{Introduction}

Currently, the number of bilingual and multilingual educational programmes is on the rise. The last four decades have witnessed several global events that have accelerated the process of globalization. These events have boosted both the spread of English as a lingua franca and the revitalization of minority and heritage languages. The change of approach that moves from a monolingual viewpoint to multilingualism has contributed enormously to developing the field of multilingual research. However, language programmes around the globe are still grounded on a monolingual bias and insist on reinforcing traditional monolingual behaviour in the language classroom. In the case of EFL instructional settings, the use of the students' first languages (henceforth, L1s) has been persistently avoided, even though in some instances it has proven beneficial. Current research (García \& Li Wei, 2014; Jones \& Lewis, 2014; Moore \& Nikula, 2016; Safont \& Portolés, 2016) has shown that the flexible use of two or more languages in the same lesson can serve a number of communicative purposes. This is what is known as translanguaging. Taking this assumption into account, the aim of this study is to identify and analyse the use of the L1, L2 and L3 by very young learners in the English as an additional language (henceforth, EAL) classroom in order to approach the actual translanguaging practices occurring in a trilingual school context.

The present research paper is structured as follows: firstly, in Section 2, we present the theoretical framework on which the study is based. There, we provide a brief introduction to the study of multilingual education and translanguaging. Afterwards, in Section 3, we describe the study itself: with its aims, research questions and method. Section 4 shows the results and discussion derived from the study. Finally, in Section 5, we reach the conclusion and put forward some suggestions and implications for further research.

\section{Translanguaging}

Our current pluralistic and globalized society has become a tremendous challenge for governments. At present, transnational agencies in Europe encourage the maintenance of linguistic diversity and favour the promotion of multilingual education. The European Commission $(2005$, p. 4) proposes that all their citizens should learn their mother tongue or first 
language and at least two other languages. This language formula implies that multilingual education should be applied in schools by adopting appropriate educational language policies. Educational programmes in the bilingual regions of Spain combine the use of the national state language, the regional language and the international language of communication (i.e. English). In this regard, the presence of more than two languages in the school curriculum is a common practice in Spain, as well as in many other countries all over the world.

Multilingual education may be understood as "the use of two or more languages in education, provided that schools aim at multilingualism and multiliteracy" (Cenoz \& Gorter, 2015, p. 2). As summarised by Portolés (2015), the main European trends related to multilingual education over the last decade have been (i) the promotion of minority and migrant languages, (ii) the early introduction of English in preschool education and (iii) the teaching of English through content, a pedagogical approach known as Content and Language Integrated Learning (henceforth, CLIL). These trends have been accompanied by an extensive body of research in the field of multilingualism and multiple language acquisition.

However, multilingual education still applies monolingual principles. In Inbar-Lourie's words (2010, p. 351), "language teaching pedagogy has tended to ignore or even suppress bilingual or multilingual options endorsing a predominantly monolingual policy, one which equates 'good teaching' with exclusive or nearly exclusive target language use". Therefore, the tendency of bilingual programmes has been the isolation of languages in the school curriculum. In those programmes, languages are conceived as separate entities and, consequently, taught separately. In fact, many multilingual teachers act as monolinguals in their classrooms, even though they are able to communicate in different languages with their students. Antón, Thierry and Duñabeitia (2015, p. 2) state that the core principle that still prevails in multilingual programmes is "the one language-one subject rule". The separation of languages as media of teaching may be influenced by early research on language acquisition in which bilinguals were seen as two deficient monolinguals in one person (Weisgerber, 1966) and the interaction among languages was regarded as detrimental. In formal schooling, a monolingual approach in the classroom does not take into account the complexity and dynamism of several language systems in multilingual practices. Hence, new pedagogical approaches, such as translanguaging, have been proposed. 
The term translanguaging was first coined by Williams (1994) to refer to a pedagogical practice in Welsh schools where two languages were employed within the same lesson. As an example, students were asked to read in Welsh and write in English. Therefore, both languages alternated. Since this first definition, the concept of translanguaging has been further developed over the last decades in line with the change of language paradigm moving from monolingualism to multilingualism (see Lewis, Jones \& Baker, 2012, for a review). At present, the term translanguaging is not only employed in education, but in all multilingual spaces, from homes to streets. In fact, translanguaging refers to "the communicative norm of multilingual communities" (García \& Sylvan, 2011, p. 389). More specifically, García (2009, p. 44) argues:

[Translanguaging] is an approach to bilingualism that is centered not on languages as has often been the case, but on the practices of bilinguals that are readily observable. These worldwide translanguaging practices are seen here not as marked or unusual, but rather taken for what they are, namely the normal mode of communication that, with some exceptions in some monolingual enclaves, characterizes communities throughout the world.

Thus, in García's view, translanguaging is a common practice in multilingual spaces that goes beyond the pedagogical practice suggested by Williams (1994). Speakers select and exclude features from their language repertoire in order to communicate both in the oral and in the written mode. Jones and Lewis (2014, p. 141) define translanguaging as "a process of establishing meaning, shaping experiences, understanding and knowledge through the use of two languages". Translanguaging considers the language practices of bilinguals not as belonging to two autonomous language systems as they have been traditionally regarded, but as part of one's unique linguistic repertoire (García \& Li Wei, 2014, p. 2). More specifically, Canagarajah (2011, p. 401) claims that translanguaging refers to "the ability of multilingual speakers to shuttle between languages, treating the diverse languages that form their repertoire as an integrated system". Such conception contrasts with a monolingual perspective according to which languages were conceived as bound systems located in separated boxes in the brain. In line with current models, such as the Dynamic Model of Multilingualism proposed by Herdina and Jessner (2002), García (2009) suggests that multilingual speakers use the language systems in their linguistic repertoire as a continuum and not as entities detached from each other. Similarly, Mondada (in Llompart Esbert, 2014: 82) states that "invece di pensare il plurilinguismo come la superposizione 
di lingue che rappresentano dei sistemi diversi che si combinano, si tratta de pensarlo come un arrangiamento di risorse", which grants "una libertà e inventività incredibile ai parlanti, perché permette loro di combinare con grande libertà le risorse linguistiche disponibili" (Llompart Esbert, 2014: 83).

The alternation, integration and flexible use of languages have proven beneficial for language learning, especially in the initial stages (García \& Li Wei, 2014; Jones \& Lewis, 2014) and in CLIL contexts (Moore \& Nikula, 2016). According to Ó Duibhir and Cummins (2012, p.36), "the central rationale for integration across languages is that learning efficiencies can be achieved when teachers explicitly draw children's attention to similarities and differences between their languages and reinforce effective learning strategies in a coordinated way across languages". Thus, the main goal of any effective multilingual language pedagogy would be to develop students' language awareness, that is, "an awakening to languages" (Cenoz, 2009, p.13). In that vein, some studies (Inbar-Lourie, 2010; Schwartz \& Alsi, 2014), focusing on the translanguaging practices used by preschool teachers in the EFL classroom, have shown that the inclusion of the students' L1s could be useful in accomplishing some instructional, managerial and/or affective purposes. In fact, those pieces of research put forward that the flexible use of one's whole linguistic repertoire may enhance L2 development.

Nevertheless, to the best of our knowledge, very few studies to date have explored the translanguaging practices of very young learners, although the one conducted by García, Makar, Starcevic and Terry in 2011 can be considered one of the few exceptions. García et al. (2011) analyse the language practices of 37 preschoolers aged 5 and 6 at a school located in the city of New York. The school follows a two-way dual bilingual programme in which Spanish and English are taught as vehicular languages. Even though classes are supposed to be only in English or only in Spanish, the authors describe how these young multilingual learners use translanguaging for six functions: (1) To mediate understandings among each other; (2) To coconstruct meaning of what the other is saying; (3) To construct meaning within themselves; (4) To include others; (5) To exclude others, and; (6) to demonstrate knowledge. According to García et al.'s (2011) findings, the most common function of translanguaging is to co-construct meaning. However, the focus of this study is on a bilingual programme, and, as far as we know, very few studies have taken into consideration the interaction of more than two languages inside the same 
lesson. For that reason, the present study will examine the translanguaging practices of preschoolers in a trilingual programme as described in the following section.

\section{The Study}

Considering research outcomes on the benefits of translanguaging in instructional settings (García \& Li Wei, 2014; Jones \& Lewis, 2014), our main goal is twofold:

(i) On the one hand, to identify the use of the L1, L2 and L3 in the EAL classroom.

(ii) On the other hand, to examine the functions served by translanguaging in the case of very young learners in the EAL classroom.

\section{Research Questions}

Taking into account the main goal stated above, the present study addresses the following research questions:

Research Question 1: What is the presence of the L1, L2 and L3 in the EAL classroom?

Research Question 2: Which are the communicative functions of translanguaging used by very young learners in the EAL classroom?

\section{Participants}

The sample consisted of 25 schoolchildren at the age of 4 and 5 from the province of Castelló (Spain). $54 \%$ of the students were female while $46 \%$ of them were male. These learners were enrolled in their second year of pre-school education and it was the first time that they were exposed to English as an additional language in the classroom. Since students had Catalan and Spanish as their L1 and L2, English was learnt as a third language (EAL). Other languages, such as Romanian and Arabic, were also used in the analysed lessons due to the large number of immigrant communities present in the local context. Therefore, we may argue that this school presents quite an interesting linguistic profile for portraying multilingual practices in instructional settings. That is why we would like to examine the instances of translanguaging that might occur and the communicative functions they perform.

The Valencian educational system offers two types of the so-called "plurilingual" programmes where pupils study through the majority (i.e. Spanish) and minority (i.e. Catalan) languages in the area, plus an international foreign language (i.e. English). We can distinguish 
between Catalan-based and Spanish-based programmes depending on the amount of exposure to these first languages. In the present study, the students were enrolled in a Catalan-immersion programme. This model implies that Catalan is the medium of instruction in most of the subjects. Spanish and English are also teaching languages in some subjects, but to a lesser extent. From our point of view, these "plurilingual" programmes are still monolingual-biased because each language is employed for a given subject at a specific period of time.

The teacher who participated in the study held a degree in Early Childhood Education as well as a degree in English Studies. Therefore, her English proficiency level may be considered advanced.

\section{Procedure and Data Analysis}

The study adopted a qualitative research approach. Classroom observation and recordings were conducted from a longitudinal perspective, namely, at three different points in time (November, February and May) during the whole academic year. The teacher was asked to carry out her daily English lessons, which mainly consisted of routines and drills, songs and stories. We collected spontaneous data on teacher-student interactions throughout three 40-minute sessions by means of audio and video recordings. Audio-recordings and audiovisual data were transcribed comprising a total amount of 9,877 words and following the transcription norms detailed in the Appendix.

In order to process our data, we employed and adapted a typology designed by García et al. (2011) for their study on translanguaging functions in a preschool classroom. The excerpts selected were analysed and coded according to the following categories (see Table 1):

Table 1. Translanguaging functions used by very young learners

\begin{tabular}{|c|}
\hline Translanguaging Functions \\
\hline (1) To mediate understandings \\
\hline (2) To co-construct meanings \\
\hline (3) To include and exclude others \\
\hline (4) To demonstrate knowledge \\
\hline
\end{tabular}

\section{Results and Discussion}

\section{Results and Discussion related to Research Question 1}

The first research question of the present study is related to the use of the L1, L2 and L3 in the EAL classroom. In order to answer the question, we examined the presence of each language 
under investigation in the EFL classroom as seen in the next figure. The percentages were calculated with reference to the total number of words produced in each language in the EAL classroom.

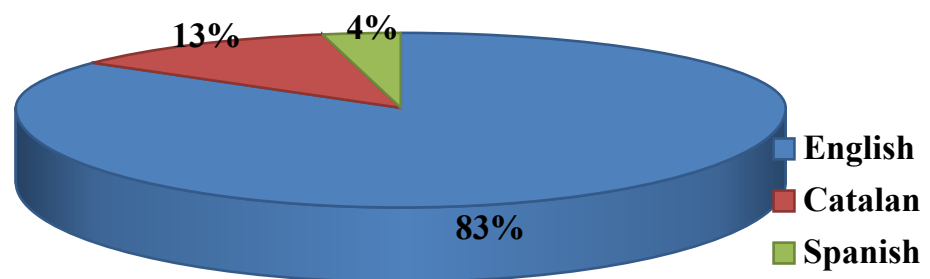

Figure 1. Presence of each language in the classroom

As illustrated in Figure 1, throughout the three recorded sessions, Catalan was used 13\% of the time, Spanish was employed 4\%, whereas English was the language of instruction $83 \%$ of the time. Thus, the occurrence of the pupils' first languages (i.e. Catalan and Spanish) in the classroom discourse does not compromise or undermine the use of the target language (i.e. English) as the main language of tuition, a must in a context where English is a foreign language and the classroom is the safest environment providing students with the main language learning conditions of input, output and feedback.

Furthermore, it is our contention that the flexible use of three languages detected in these lessons (i.e. Catalan, Spanish and English) does not merely imply a random shift of code choice, due to lack of linguistic knowledge, but the complete use of one's multilingual repertoire as an interrelated system of resources, acting here, as we will see in the next section, as a facilitator in the understanding and processing of the target language.

The results derived from our study, then, acknowledge the presence of the L1, L2 and L3 in the EAL classroom. Translanguaging in classroom discourse occurs in all different stages of education, but it is especially relevant to very young learners who cannot read and write and mostly learn thanks to a fruitful dialogue with their teacher. Therefore, translanguaging does occur in the EAL classroom since the flexible use of languages is a common practice in multilingual instructional contexts, despite the fact that lessons are supposed to be exclusively taught through the target language (i.e. English). As previously stated, our subjects were enrolled 
in programmes which supposedly follow monolingual academic standards, that is, languages are taught separately by using the language-time strategy.

Traditionally, the use of multiple languages in the EFL classroom has been avoided in order to prevent cross-linguistic contamination, despite the fact that no research has proven the validity of that assumption. The attainment of an ideal native speaker's competence has been the goal of most EFL programmes, although this is no longer the case as far as EAL is concerned. In fact, multilingual speakers use their whole linguistic repertoire in order to communicate strategically and effectively. Thus, the disapproval of resorting to several languages in the school context is not a realistic approach to early language teaching/learning, since our data showed that they do not compromise language learning. What is more, the use of multiple languages by very young students may accomplish different interpersonal functions and fulfil a number of communicative intentions, which might be seen as an asset instead of as a hindrance, as we will see in the following section.

\section{Results and Discussion related to Research Question 2}

The second research question guiding the present investigation referred to the functions of translanguaging employed by very young learners in preschool EAL classroom discourse. In order to analyse such functions, we employed the typology used by García et al. (2011) as previously mentioned in the section devoted to the Method.

The total number of functions found is 104. As illustrated in Figure 2 below, to mediate understandings is the most common one employed in the EAL classroom when translanguaging takes place. This function represents $36 \%(n=37)$ of the total number of exchanges, followed by the function of including and excluding others, that accounts for $27 \%(n=28)$; and being the third function identified that of showing knowledge, with a $21 \%(n=22)$ of the occurrences. The least common function of translanguaging is to co-construct meaning, as it amounts to $16 \%(n=17)$ of the corpus as a whole. In what follows, we will illustrate these four functions with an example. All of them belong to the same lesson in which students were reviewing the colours. 


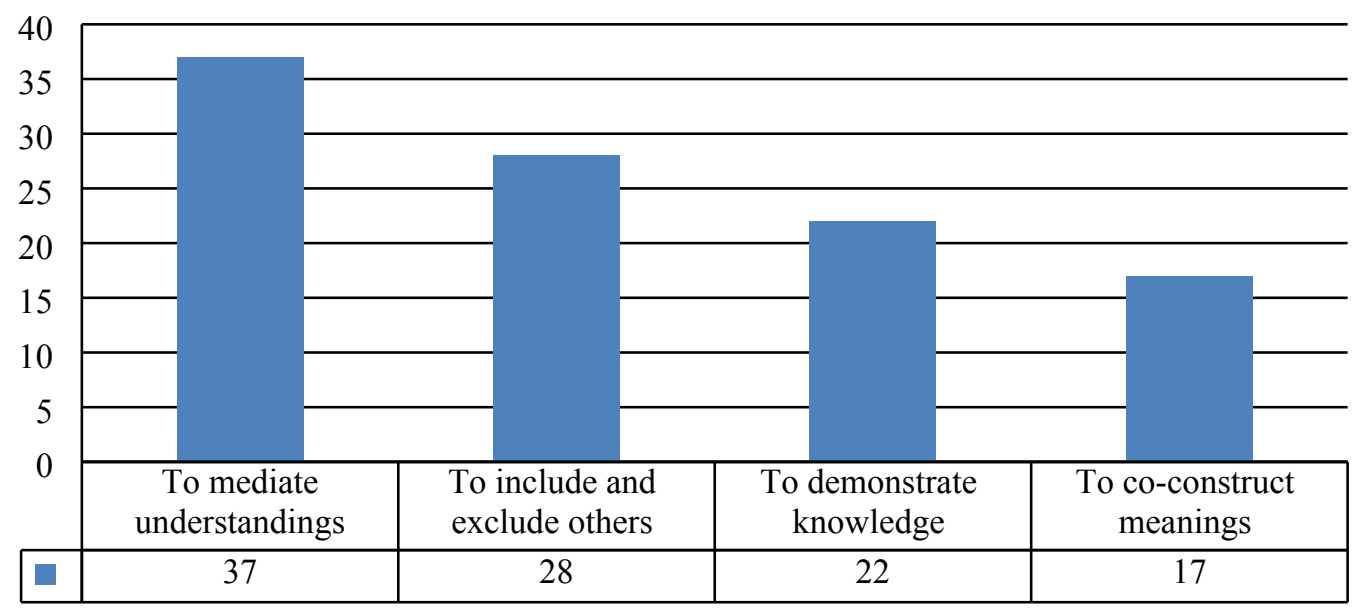

Figure 2. Functions of translanguaging performed by very young learners

Example 1 below shows an excerpt corresponding to the 'mediate understandings' function. In this type of function, the pupils use their whole language repertoire in order to communicate effectively. Interpretations, explanations and direct translations are examples of this function. For instance, in Example 1, the teacher tells a boy to be quiet. Since Omar continues speaking, another student resorts to Catalan in order to warn him. S1 provides Omar with an interpretation that facilitates his understanding of what the teacher has just said.

\section{Example 1}

T: Please, Omar, silence!

(3.0) (Omar continues speaking)

S1:La mestra diu que te calles Omar.

(The teacher tells you to be quiet)

Regarding the function 'co-construct meaning', very young learners use their previous knowledge from their linguistic repertoire in order to create new concepts and establish relationships among languages. As shown in the following excerpt corresponding to the 'co-construct meaning' function (see Example 2 below), the teacher asks for the colour of a skirt and a student responds blau. This is the Catalan word for blue. The teacher repeats the word blau with an exaggerated intonation and the student identifies that the word blau is for Catalan, whereas blue is the appropriate word for English. Here, this young learner from Moroccan origin has to make himself understood by means of translanguaging. We have to take into consideration that he is learning four languages at the same time: his mother tongue (Arabic), the environmental languages of the 
context (Catalan and Spanish) and English as an additional language. He becomes aware of his own learning by resorting to his skills and capacities as language learner.

\section{Example 2}

T: a skirt very good, this is a skirt and these are trousers, what colour is the skirt Mutard? what colour is the skirt Mutard?

S2: blau

$\mathrm{T}$ : blau? ((ss laughter))

S2: ahh no blue::, blau es valenciano (Ah!, no, blue. Blau is Catalan).

A closer look at Example 2 reveals the extent to which the teacher is presented with a situation where her pupils" "other" languages might have been introduced and compared to explore the relationships existing among them. This would have been an excellent learning opportunity to integrate languages also present in their linguistic repertoires and to further develop students' metalinguistic awareness. For instance, the teacher might have proposed an activity in which the word blue had been studied in depth. The similarity of colour names, such as blue (English), blau (Catalan), bleu (French), blu (Italian) could have been contrasted with azul (Spanish) that comes from Arabic. Therefore, creating connections among languages in the classroom through translanguaging might prove fruitful to make the most of the pupils' whole linguistic repertoire.

Turning to the function of including and excluding others, Example 3 below shows how very young learners like taking part in classroom activities and seeing themselves as part of the group. For instance, in this case, student 3 draws the teacher's attention in Spanish in order to claim his right to participate in the activity.

\section{Example 3}

T: Fátima, which colour do you want?

S3: eeee y nosotros dos?

(Oi! And the two of us?)

T: Alba Alba if you speak speak speak this arrow for me ok Carlos if you speak speak speak this for me ok

Similarly, very young learners also like to exclude others, as we can see in line 3 at the beginning of Example 4. Here, the teacher asks Alba which colour she prefers. She responds orange and, then, another student, S5, claims in Catalan that Alba had already chosen pink. This may be seen as an instance of exclusion. However, in the same dialogue (see line 6) another example of inclusion can be identified. In this case, the very same student who wanted to exclude 
Alba now seems to be happy when another classmate (i.e. Arantxa) selects the same colour which had been previously chosen. Therefore, S5 resorts to her whole linguistic repertoire (either Catalan or Spanish) depending on the function she intends to accomplish and/or the addressee she is talking to.

\section{Example 4}

T: Alba which colour do you want? green, yellow, pink, orange?

S4: orange

S5: Alba tu tenies un rosa

(Alba, you had pink)

T: uyyy she can change the colour orange. Arantxa, what colour do you want?

S6: pink

S5: iguales ((laughter))

(Same!)

The last function documented refers to that of demonstrating their knowledge. Preschoolers love showing off what they have learned about English either in class or outside it, as we can see in the following example.

\section{Example 5}

T: do you know what is black?

S: black es un color en inglés

(Black is a colour in English)

T: ah!

S: yo lo sé porque un día me lo dijo mi tete

(I know it because my bro told me)

T: your brother?

S: sí, el tete

(Yes, my bro)

$\mathrm{T}$ : yes (.) black, this is colour black

Those examples above have illustrated instances of translanguaging used by preschoolers in the EAL classroom. As we have seen, translanguaging is very dynamic and highly unpredictable. Very young learners use their entire linguistic repertoire in order to successfully communicate, make meaning and reinforce their multiple identities. The preliminary results derived from this study, then, have shown the great variety of linguistic resources employed by multilinguals in communicative interaction and we may argue that translanguaging in the EAL classroom is versatile and purposeful. 


\section{Conclusions and pedagogical implications}

Translanguaging makes reference to the flexible use of languages from a speaker's entire linguistic repertoire. The present study confirms that the EAL classroom in multilingual contexts is not and should not be monolingual, as the L3 or additional language inevitably and fortunately interacts with the other languages known to pupils. Our young learners use their L1, L2 and L3 in order to communicate effectively and make sense of their worlds. Language systems in multilingual minds can serve different purposes as seen in this study. More specifically, the functions performed by translanguaging in preschool EAL classroom discourse have been (i) to mediate understandings, (ii) to include and exclude others, (iii) to co-construct meaning and (iv) to demonstrate knowledge.

We believe that translanguaging practices in the EAL classroom show a more realistic and complete picture of our participants' linguistic behaviour both inside and outside the school. Additionally, the flexible use of their entire linguistic repertoire may be beneficial for language learning, as other studies have pinpointed (García \& Li Wei, 2014; Jones \& Lewis, 2014; Nussbaum, 2014; Safont \& Portolés, 2016). With that, we are not saying that an overuse of other languages is the optimal scenario to teach English as an additional language, but we argue that they should not be forbidden as it has been traditionally the case, taking for granted that their presence will always be harmful.

Translanguaging could also be considered as an inclusive and integrational approach to educate all children in the classroom, regardless of their linguistic and cultural background. It may help, as pinpointed by Nussbaum (2014, p. 10), to increase communication between teachers and students and among students themselves by accepting other languages into the English classroom. Therefore, translanguaging may break down boundaries between speakers of specific languages and cultures and, thus, encourage integration of foreign students in the educational system.

Yet, transforming translanguaging in an effective teaching resource for early language learning of English as an additional language (EAL) involves improving teacher training. Being open to children's multilingual practices in English lessons is just a first step in the construction of a multilingual pedagogy. To make the most of translanguaging as a pedagogical approach, beyond just allowing it as a scaffold, when learners face difficulties in terms of understanding the target language, teachers need some guidance. 
In Ballinger's words, we have to move towards "a cross-linguistic pedagogy, which must help students make links between languages, whether it is through the content they are exposed to or through peer interaction" $(2015$, p. 56). Resourcing to cognate instruction as in the follow-up activity we suggested in Example 2 is one of a number of pedagogical interventions available to teachers and designed to enhance their language learners' metalinguistic awareness. The challenge now is turning teachers' readiness into teachers' preparation and, doing so, not only to consolidate bilingual programmes but also multilingual ones.

This is a very preliminary study and we are aware of a number of limitations. For future research, we would like to improve the adapted typology from Garcia et al. (2011) and include more translanguaging functions. Additionally, it would be interesting to include a wider range of age groups and different educational settings, such as Spanish-based models and/or CLIL programmes.

\section{References}

Antón, E., Thierry, G., \& Duñabeitia, J.A. (2015). Mixing languages during learning? Testing the one subject-one language rule. PLoS ONE, 10(6), e0130069. doi: 10.1371/journal.pone.0130069.

Ballinger, S. (2015). Linking content, linking students: a cross-linguistic pedagogical intervention. In J. Cenoz \& D. Gorter (Eds.), Multilingual education. Between language learning and translanguaging (pp. 35-60). Cambridge: Cambridge University Press.

Canagarajah, S. (2011). Codemeshing in academic writing: Identifying teachable strategies of translanguaging. The Modern Language Journal, 95, 401-417. doi:10.1111/j.15404781.2011.01207.

Cenoz, J. (2009). Towards multilingualeEducation: Basque educational research from an international oerspective. Bristol: Multilingual Matters

Cenoz, J., \& Gorter, D. (2015). Towards a holistic approach in the study of multilingual education. In J. Cenoz \& D. Gorter (Eds.), Multilingual education: between language learning and translanguaging (pp. 2-15). Cambridge: Cambridge University Press.

European Commission (2005). A new framework strategy for multilingualism. Retrieved December 13, 2015, from http://eur-lex.europa.eu/legalcontent/EN/TXT/?uri=uriserv:c11084

García, O. (2009). Bilingual education in the 21st century: A global perspective. Oxford: Blackwell.

García, O. \& Wei, L. (2014). Translanguaging: Language, bilingualism and education. New York: Palgrave Macmillan.

García, O., \& Sylvan, C. (2011). Pedagogies and practices in multilingual classrooms: singularities and pluralities. The Modern Language Journal, 95(3), 385-400. doi:10.1111/j.1540-4781.2011.01208 
García, O., Makar, C., Starcevic, M., \& Terry, A. (2011). The translanguaging of Latino kindergartners. In J. Rothman \& K. Potowski (Eds.), Bilingual youth: Spanish in English speaking societies (pp. 33-55). Amsterdam: John Benjamins.

Herdina, P., \& Jessner, U. (2002). A dynamic model of multilingualism: Perspectives of change in psycholinguistics. Clevedon: Multilingual Matters.

Inbar-Lourie, O. (2010). English only? The linguistic choices of teachers of young EFL learners. International Journal of Bilingualism, 14(3), 351-367. doi:10.1177/1367006910367849

Jones, B., \& Lewis, G. (2014). Language arrangements within bilingual education. In E.M. Thomas and I. Mennen (Eds.), Advances in the study of bilingualism (pp.141-170). Bristol: Multilingual Matters.

Lewis, G., Jones, B., \& Baker, C. (2012) Translanguaging: origins and development from school to street and beyond. Educational Research and Evaluation: An International Journal on Theory and Practice, 18 (7), 641-654. doi:10.1080/13803611.2012.718488

Llompart Esbert, J. (2014). Resources en transformation: multimodalitat, plurilingüismo, acquisizione -seen from an interactional perspective. Una entrevista amb Lorenza Mondada. Bellaterra Journal of Teaching \& Learning Language \& Literature, 7 (4), 79 87.

Moore, P., \& Nikula, T. (2016). Translanguaging in CLIL classrooms. .In T. Nikula, E. Dafouz, P. Moore, \& U. Smit (Eds.), Conceptualising Integration in CLIL and multilingual Education (pp. 211-234). Bristol: Multilingual Matters.

Nussbaum, L. (2014). Una didàctica del plurilingüisme. Bellaterra Journal of Teaching \& Learning Language \& Literature 7 (4), 79-87.

Ó Duibhir, P., \& Cummins, J. (2012). Towards an integrated language curriculum in early childhood and primary education (3-12 years): Commissioned research report. Dublin: National Council for Curriculum and Assessment.

Portolés, L. (2015). Multilingualism and very young learners: An analysis of pragmatic awareness and language attitudes. Boston: De Gruyter. doi:10.1515/9781501500022

Safont, P. \& Portolés, L. (2016). Pragmatic functions of formulaic speech in three different languages: A focus on early L3 learners of English. Journal of immersion and contentbased language education, 4 (2), 225-250.

Schwartz, M., \& Asli, A. (2014). Bilingual teachers' language strategies: The case of an ArabicHebrew kindergarten in Israel. Teaching and Teacher Education, 38, 22-32. doi: 10.1016/j.tate.2013.10.013.

Weisgerber, L. (1966). Vorteile und Gefahren der Zweisprachigkeit. [Advantages and dangers of bilingualism]. Wirkendes Wort, 16, 73-89.

Williams, C. (1994). Arfarniad o ddulliau dysgu ac addysgu yng nghyd-destun addysg uwchradd ddwyieithog [An evaluation of teaching and learning methods in the context of bilingual secondary education] (Unpublished PhD thesis). Bangor: University of Wales.

\section{Acknowledgements}

As members of the LAELA (Lingüística Aplicada a l'Ensenyament de la Llengua Anglesa) research group at Universitat Jaume I (Castellón, Spain), we would like to acknowledge that this study is part of a research project funded by (a) Universitat Jaume I P1·1B2015-20, E-2015-03 and E-2015-30 and (b) projecte de la Unitat de Suport Educatiu 3093/15 and 3252/16. 


\section{Appendix: Transcriptions Conventions}

$\begin{array}{ll}. & \text { Falling intonation } \\ ? & \text { Rising intonation } \\ ! & \text { Exclamation talk } \\ , & \text { Comma indicates a level, continuing intonation; suggesting non-finality } \\ {[\text { ] }} & \text { Brackets indicate overlapping utterances } \\ (.) & \text { Period within parentheses indicates micropause } \\ (2.0) & \text { Number within parentheses indicates pause of length in seconds } \\ (\text { yes }) & \text { Parentheses indicate transcriber doubt about hearing of passage } \\ (\text { xxx }) & \text { Unintelligible speech } \\ ((\text { laughter) }) & \text { Aspects of the utterance, such as whispers, coughing, and laughter, are } \\ & \text { indicated with double parentheses. } \\ \text { SS } & \text { Students } \\ \text { Sn } & \text { Unknown Student } \\ \text { S1 } & \text { Student } 1 \\ \text { T } & \text { Teacher } \\ \text { R } & \text { Recorder }\end{array}$

\section{Authors' information}

Laura Portolés is an Assistant Professor and member of the LAELA research group at Universitat Jaume I, Spain (http://gruplaela.uji.es/). Portolés finished her $\mathrm{PhD}$ in Applied Linguistics under the supervision of Pilar Safont Jordà in December 2013. Her research interests include third language acquisition, affective factors, early pragmatic development and multilingual education. She has recently published an international volume entitled Multilingualism and Very Young Learners: An Analysis of Pragmatic Awareness and Language Attitudes (De Gruyter, 2015).

Email: 1portole@uji.es

Otilia Martí is an Assistant Professor in the Department of Education and member of the LAELA research group at Universitat Jaume I, Spain (http://gruplaela.uji.es/). Martí finished her PhD in Applied Linguistics under the supervision of Maria Pilar Safont Jordà in December 2010. Her research interests include the acquisition of English as a third language and multilingual education with a special focus on Infant and Primary teacher training, as well as the impact of the variable gender on interlanguage pragmatics. She has coedited volumes on both fields of enquiry, such as Achieving Multilingualism: Wills and Ways with Maria Pilar Safont-Jordà (2008) or Refusals in instructional contexts and beyond with Patricia Salazar-Campillo (Rodopi, 2013).

Email: omarti@uji.es

To cite this article:

Portolés, L., \& Martí, O. (2017). Translanguaging as a teaching resource in early language learning of English as a an additional language (EAL). Bellaterra Journal of Teaching \& Learning Language \& Literature, 10(1), 61-77. DOI: $\underline{\text { http://dx.doi.org/10.5565/rev/jt13.698 }}$

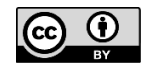

